\title{
Excursions
}

Volume 4, Issue 1 (June 2013) Science/Fiction

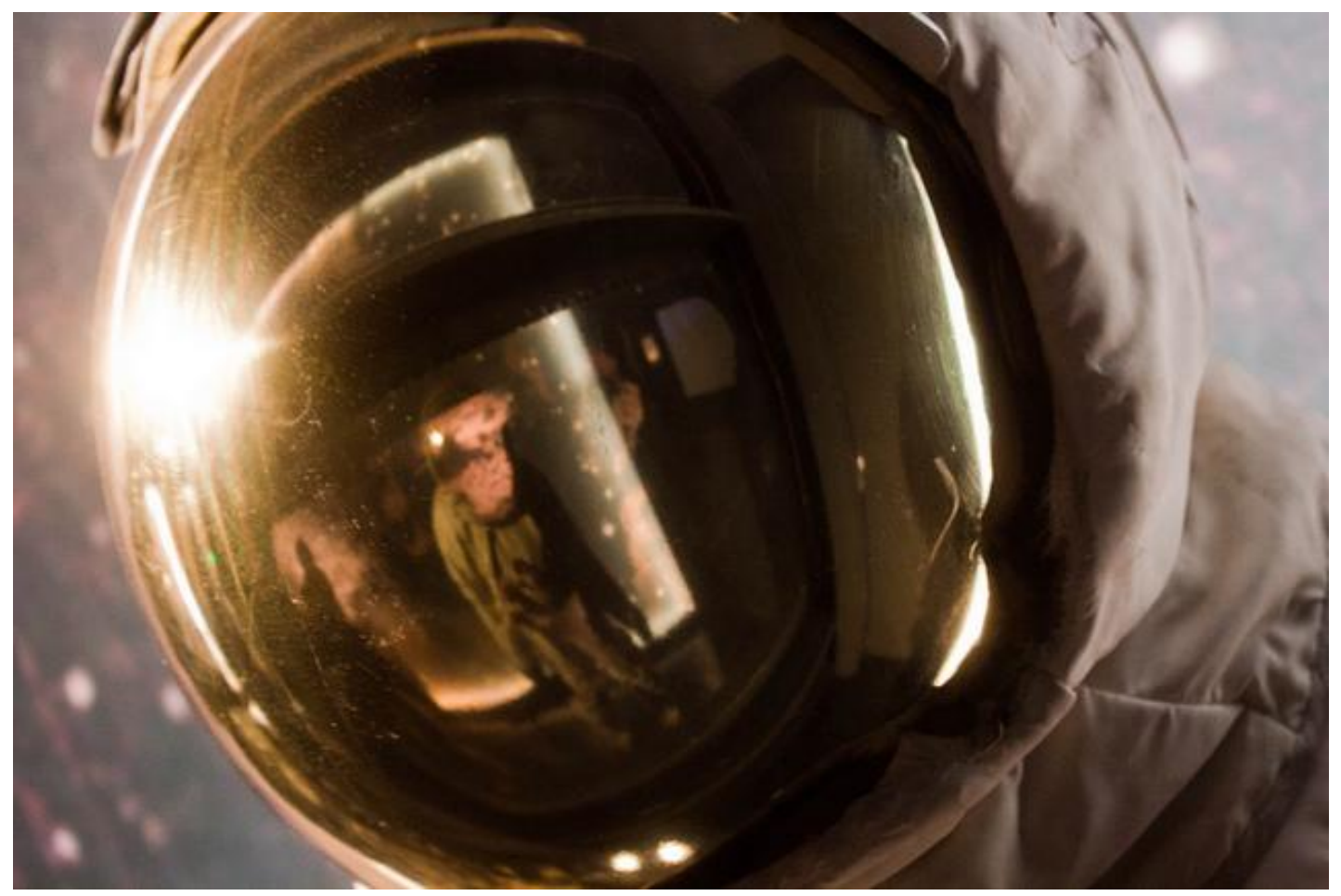

Image credit: Tangi Bertin (www.flickr.com/photos/tangi_bertin/) CC by 2.0

Ben Wetherbee and Stephanie Weaver, "'You Know the Business and I Know the Chemistry": The Scientific Ethos of Breaking Bad",

\author{
Excursions, vol. 4, no. 1 (2013)
}




\section{"You Know the Business and I Know the Chemistry": The Scientific Ethos of Breaking Bad}

"You know the business and I know the chemistry. I'm thinking, maybe you and I could partner up". So speaks 50-year-old high school chemistry teacher Walter White (Bryan Cranston) to his former student, twenty-something small-time crystal methamphetamine dealer Jesse Pinkman (Aaron Paul), in the pilot episode of Vince Gillian's hit TV series Breaking Bad (Pilot 2008). The quote is prescient for a number of reasons. First, it logically unites the show's two central characters; Walt, a scientific genius recently diagnosed with terminal lung cancer, intends to bequeath the easy money earned in the meth industry to his family, while Jesse has recently lost his meth-cooking partner to a D.E.A. bust lead by Walt's brother-in-law. The union of Walt's scientific acumen with Jesse's experience in the drug trade sets the tumultuous narrative rolling. The quote also speaks to an enduring dialectic within the show between matters of science and economics-a commentary on market forces' dictation of which practices are allowed (and by whom), and on the capabilities of science to determine the shape of the economic market. Finally, there exists a comparable dialectic between business and science that characterises 
Breaking Bad's marketing and reception as a commercial and cultural product in the real world. In this essay, we focus primarily on this final point-on how the show has rhetorically used science to its own advantage, to garner praise and credibility as a distinctive and "serious" television programme.

This essay also necessarily addresses the interplay between science, fiction, and the various shades of "science fiction". Breaking Bad is a fictional programme that has invoked numerous beguiling images of science happening-the donning of hazmat suits, the decanting of chemicals into flasks and beakers-and has deployed the nomenclature of chemistry in its dialogue-terms like alknes and diolefins-while resisting the tag of "science fiction”. On one hand, there is some irony in the generic labelling of Breaking Bad as a crime drama or thriller while the show exhibits science more frequently and ostentatiously than the many "real" science fiction TV shows or films that presuppose, for example, space travel, teleportation, or artificial life to be facts of their narrative worlds, but keep tacit the science behind such innovations. On the other hand, one could argue that Breaking Bad is no more about chemistry than Rear Window is about the telescopic camera or Casablanca is about running a gin joint. The show's science functions more as a narrative catalyst-to use an aptly chemical metaphor-than a body of subject matter; Walt's chemistry provides the opportunity for Breaking Bad's storyline to probe the social and economic issues of the American family, capitalism, the War on Drugs, and American-Mexican border relations (the show is set in Albuquerque, New Mexico). Chemistry is a point of access into the show's "serious" subject matter.

As the show has progressed, its later seasons have brushed the chemistry of meth-cooking into the background-it becomes something that happens, but not something to showcase-in favour of further attention to the many characters' interpersonal and social relationships. Such a change in emphasis has occurred, notably, only after Breaking Bad cemented its reputation as a programme dealing with science: the show has evolved, and continues to evolve, but only after establishing a name for itself as "that great show about the chemistry teacher who cooks meth". Here, we posit the importance of science not in Breaking Bad's subject matter, but in its ethos-in the classical rhetorical sense of the word, as a construction of character and credibility. The show has invoked images and discourses of science to create part of a collective 
character, one that suggests intelligence, realism, and distinction from other crime drama. We discuss Breaking Bad's scientific ethos in three sections below: the first briefly theorises the nature of ethos in serial, televisual texts; the second examines the textual construction of Breaking Bad's ethos through its aesthetics, characters, and narrative; the third discusses the intertexual and social effects of that ethos.

\section{The Ethos of Serial Television Narratives}

The ethos of a multi-authored serial text is a thorny matter. In Rhetoric Book I, chapter 2, Aristotle deems appeals to ethos, the rhetorical construction of "human character and goodness", as a necessary component of any piece of persuasive discourse, along with appeals to logos (logical reasoning) and pathos (stirring of emotions) (1954, 1356a20-25). Aristotle theorises further that the rhetor (practitioner of rhetoric) should not rely on the audience's preconceptions of his own character, but establish credibility and goodwill to his audience while speaking (1954, 1356a5-10). A TV show, though, calls for a different set of rules than a piece of civic oratory; though Aristotle's remains the most influential and widely cited treatise on rhetoric, it stands to reason that rhetorical practice has changed drastically since the days of ancient Athens where "rhetoric" referred exclusively to civic oratory. Multi-authored texts-or those authored "by committee" as Seymour Chatman puts it, like television, films, or the Bible (Chatman's examples)-dispute Aristotle's classical paradigm of the autonomous ethos tethered to a single rhetor (1978, pg. 149; see also Chatman 1990, pg. 84). A show like Breaking Bad also introduces the complexity of serialisation: a rhetorical performance that spans years, evolving through numerous seasons and episodes, while maintaining thematic and ideological coherence amongst its parts. ${ }^{1}$ The ethos of Breaking $\mathrm{Bad}$, then, is at once composite and emergent: it is the sum of numerous aesthetic and narrative choices from numerous contributors (actors, writers, directors, producers), and it is constructed through the televisual text each time a viewer watches Breaking Bad. But the ethos of any effective serial narrative is also cumulative: it builds on itself and evolves as episodes and seasons pass. 
One of the fullest articulations of how ethos emerges through narrative texts resides in Wayne Booth's (1983) term "implied author", which Booth coins in The Rhetoric of Fiction to denote a middle space between the "real" flesh-and-blood author and her textual creations (the narrator, characters, plot, etc.). The implied author, then, is just that, the authorial presence implied by the text and inferred by the reader (or viewer): not Charles Dickens the man, but "Charles Dickens" the authority reconstructed through attention to his texts. When thinking about the implied author of a television narrative, though, one should not pick a solitary author and go searching for that individual's self-recreation as the ethos of the text. One oversimplifies in naming Breaking Bad creator Vince Gilligan the show's author, and presuming that the program's every facet extends from Gilligan's executive choice. More to the point, in terms of the show's rhetorical effects, we doubt that many of Breaking Bad's viewers perceive Gilligan as the show's author, anyway-or even that a large percentage of the viewership knows who Gilligan really is. Rather, Breaking Bad's most recognisable human name and face are those of its star, Bryan Cranston. And while Cranston's performance as Walt does matter immensely to the show's ethos and ability to conjure scientific imagery and discourse, it would not suffice, either, to simply ascribe "implied author" status to Cranston's self-presentation in the show. There are too many other important actors and contributors.

The implied author of a complex, audiovisual serial narrative like Breaking Bad can only be understood as the sum of numerous choices-verbal, visual, writerly, actorly, and so on-all perceived as a coherent whole. As Chatman puts it, "The source of the narrative text's whole structure of meaning-not only of its assertion and denotation, but also of its implication, connotation, and ideological nexus-is the implied author". The term is helpful, Chatman continues, because it supplies "a way of naming and analyzing the textual intent of narrative fictions under a single term but without recourse to biographism" (1990, pg. 75). It is especially helpful for thinking about the ethos of a television show, we would add, because it evades the drudgework of researching every creative contributor who might have affected the aesthetic presentation, narrative arc, and ideological underpinnings of Breaking Badand, more importantly, because it voices the human will to perceive a unified consciousness and character, an ethos, even behind a text as multi-authored 
and multi-vocal as a television show. ${ }^{2}$ The implied author at work behind Breaking Bad, suffice to say, is an enormously complicated construction. We do not intend to provide a full account of that construction here; indeed, we cannot because each viewer infers the ethos of Breaking Bad differently, her perception determined by a spectrum of variables and biases, both individual and social. But we hold that the show's use of science supplies an important constant, a recurring set of ethical appeals that has influenced the way most viewers perceive the show. This is not to say that the implied author behind the show is a scientist; rather, the implied author dons the mask (or hazmat suit, if you prefer) of the knowledgeable chemist as one of her most important guises.

\section{Walter White and the Rhetorical Use of Science}

In Breaking Bad's short title sequence, which has not changed since its first episode, a series of chemical terms and molecular formulas-chief among them $\mathrm{C}_{10} \mathrm{H}_{15} \mathrm{~N}$, the formula for methamphetamine-are seen drifting backward in a green fog that looks like a chemical byproduct. The periodic table of elements then comes into focus, after which the chemical symbols for the halogen bromine $(\mathrm{Br})$ and the metal barium $(\mathrm{Ba})$ crystallise on the screen to help spell out the title: Breaking Bad. As the opening credits begin, the same motif recurs: Bryan Cranston's name again includes the chemical symbol for bromine; the name of AnNa Gunn (Walt's wife, Skyler) displays the symbol for sodium; AAron Paul (Jesse) represents the noble gas argon; DeaN Norris (Walt's D.E.A. agent brother-in-law, Hank) represents nitrogen; and so on. Apart from phonic convenience, there seems to be little reason for which chemical symbols appear in which actors' names, but this exhibit of chemical semiotics does have two important effects vis-à-vis the show's scientific ethos: (1) broadly speaking, it sets a tone at the beginning of each episode (even those installments which deal very little with actual chemistry), reminding viewers of the show's investment in scientific accuracy; and (2) it forms a narrative metacommentary whereby the actors who play Walt's family, associates, and enemies are presented in Walt's terms. While Breaking Bad invests itself in a bevy of important characters, the appeals to scientific credibility double as a reminder that, from one perspective, it's still Walt's show. 
Such emphasis on Walt is important because he is, amongst other things, Breaking Bad's mouthpiece for scientific credibility. Periodically, in the first three seasons, viewers see Walt addressing his high school chemistry classes. One characteristic piece of dialogue goes like this: "Monoalkynes, diolefins, trienes, polyenes-the nomenclature alone is enough to make your head spin. But when you start to feel overwhelmed, and you will, just keep in mind that one element, carbon. Carbon is at the centre of it all. There is no life without carbon" (Peekaboo 2009). The opening set of terms will likely puzzle most viewers just as they puzzle Walt's students. These are specialised chemical terms; the writers could have fabricated replacements that would make equal sense to most of the show's viewers. Yet, the show's creators hired Donna Nelson, a professor of organic chemistry at the University of Nebraska in Norman, to ensure the correct use of scientific language and correct representation of scientific practice in the show (Flatow and Nelson 2011). As David A. Kirby (2011, pp. 97-117) notes, it is commonplace for filmmakers and TV producers to consult with scientific experts, but rare that a TV show or film take scientific accuracy as seriously as does Breaking Bad; more often than not, writers and directors fudge scientific accuracy for the sake of "dramatic needs". ${ }^{3}$ On the terrain of specialised science, the average viewer would rarely notice an occasional misstep, and yet, as Nelson puts in an interview on National Public Radio's Talk of the Nation, “[F]or scientists, when we see science portrayed badly, you know, inaccurately on television or in the movies, it's like fingernails on the blackboard" (Flatow and Nelson 2011). 4 Thus, the show's correct usage of scientific discourse works as an appeal to credibility both by gratifying the small contingent of its audience who are familiar with the discourse of chemistry-they will, that is, conceive of the show's implied author as someone who knows her chemistry well enough-and pre-empting public critique from that same contingent and other scientific authorities.

On the other hand, as we point out above, Breaking Bad is only in the loosest sense a show about chemistry. One could not, for example, carefully study the show's depictions of meth-cooking and then replicate the process, or even come close. Instead, the show employs what the user-maintained website TV Tropes cleverly terms the "And Some Other Stuff" trope (TV Tropes Foundation [no date]): it explicitly lists some of the ingredients and equipment necessary to cook meth, but leaves explication of the process purposefully 
incomplete-reduced, in the end, to a montage of bubbling fluids and scientific banter, all of which necessarily omits all that necessary "other stuff" one would need to know and possess to cook meth. This trope pre-empts indictments of the show as a how-to manual for meth cooking, but it also allows the show to create the verisimilitude of "serious" science, and to use that science for various rhetorical ends, without investing too much narrative effort in the chemistry itself.

By invoking shorthand images of chemistry, the show allows space for its other narrative investments. One key use of Walt's scientific acumen is to create a series-long dialectic between science and masculinity. This interplay warrants attention here because Breaking Bad's use of science provides more than scientific credibility; it also provides a sort of generic credibility whereby Walt uses science to occupy the individual masculine lead viewers expect (and perhaps require) to helm a gritty crime drama. Appeals to scientific credibility also provide Walt a "way in" to the role of the masculine lead, while allowing him to keep his interesting character quirks as well. 5

These quirks are especially visible in early episodes, where Walt frequently appears as bumbling and awkward in social settings. The pilot introduces him as an emasculated teacher and husband, disrespected by the male teenagers he teaches while at home his wife nags him about taking vitamin supplements and reprimands him for buying printer paper with the wrong credit card (Pilot 2008). Walt also fails repeatedly to confront other men with proper machismo; he botches his encounter with drug-trade goons and makes a poor first impression on meth kingpin Gustavo "Gus" Fring (Giancarlo Esposito), who becomes Walt's boss in seasons 3 and 4 . However, Walt never fails at his chemistry, and Breaking Bad ensures that viewers never doubt his scientific abilities; the show informs viewers about Walt's scientific background-his education at Caltech, his cofounding of a successful technology company, and his research that contributed to a Nobel Prize (Gray matter 2008; 'Pilot' 2008). By establishing Walt's credentials, Breaking Bad effective establishes its own credentials, too; it defuses scepticism about Walt's ability to do chemistry, thereby reinforcing the credibility of its own representations of "real" science.

This trust in Walt to scientifically perform under pressure also connects directly to how the show conceives of its main character's masculinity. In the 
pilot, viewers first see Walt making use of chemistry; wearing only underwear and an apron, he works with Jesse, mixing chemicals in an RV in the middle of the desert using equipment swiped from the high school chemistry lab. Walt's castigations of Jesse for using the wrong flask and allowing anonymous chemicals to boil over within the cramped RV appear off-putting and ridiculous, but somehow more "real" in their ridiculousness when compared to those shorthand images of pristine laboratories, white coats, and rubber gloves, that film and television typically invoke to illustrate scientific procedure. Walt's next task, in the second episode, seems more ridiculous yet: after killing a hostile drug dealer with an impromptu cloud of mustard gas, he must help Jesse track down an appropriate container for liquefying the body in acid (Cat's in the bag... 2008). Most depictions of chemistry in the first two seasons are messy, disorganised affairs showcasing Walt's chemistry genius in the face of limited resources and bad odds. It is through this messiness, though, that Walt emerges as something close to a classic, masculine protagonist. In one episode midway through the first season, viewers witness what might be called Walt's first real crescendo of masculinity. Carrying only a bag of fulminated mercury crystals, visually indistinguishable from crystal meth, he confronts the sociopathic crime boss Tuco Salmanca (Raymond Cruz) whose men had recently robbed and beaten Jesse (Crazy handful of nothin' 2008). Walt introduces himself as "Heisenberg"-an allusion to the German theoretical physicist Werner Heisenberg, known for his atomic research during World War II-before tossing a mercury crystal against the floor and blowing out the room's windows. Walt's gutsy play earns him compensation for the meth Tuco had stolen, as well as Tuco's business partnership.

This birth of "Heisenberg"-Walt's crime-boss alter ego-can also be seen as Walt's rebirth as an individualist masculine anti-hero, a classic component of the crime drama genre. In a season 2 episode (Over 2009), audiences view the complete oscillation from Walt, the teacher and family man, to Walt-asHeisenberg over the course of one scene. While shopping for home repair supplies at the hardware store, Walt notices a man buying large volumes of acetone, lye, "and some other stuff" needed for meth-cooking. Walt's first instinct is to offer advice: "Don't buy everything in one place. Do it piecemeal. Different items, different stores-attracts less attention”. Later, though, Walt 
approaches the man and his partner in the parking lot as Heisenberg. "Stay out of my territory", he tells them.

Walt, thus, grows into a flexible and complex character, at once the docile family man and the ominous anti-hero. However, the beginning of Walt's tenure as Gus's cook in season 3 signals a change in both scenery and narrative emphasis: as Walt takes up residence in Gus's state-of-the-art meth lab underneath an industrial laundry mat, Breaking Bad ceases its investment in displaying the science behind meth-production, opting instead for further attention to the economies and social ramifications of the drug trade. Gus's sterile lab signals a reversion to shorthand images of science: instead of elaborate montages of careful measure in intimate spaces, audiences occasionally see Walt or Jesse dump a jug of chemicals into a setting tank; the show's cameras lose their interest in capturing the intricacies of chemistry. Even the one episode that takes place entirely within the lab displays very little chemistry, instead focusing on Walt's obsession with catching a loose fly that threatens to contaminate the product (Fly 2010).

Walt, moreover, loses his status as Heisenberg once he enters Gus's lab, and the third and fourth seasons can be read as Walt's quest to reclaim that identity. He becomes increasingly feminised under Gus's watch: viewers often spend more time watching Walt and Jesse clean the lab than actually make meth, while their mistrustful employer's security cameras and henchman look on. Indeed, Michel Foucault's works Discipline and Punish (1995) and Birth of the Clinic (1975) would pose an interesting commentary on Walt's marginalised positions as a cancer patient in the hospital and a panoptic subject in the lab. ${ }^{6}$ Both settings, in contrast to his makeshift RV lab, see Walt in a vulnerable position, unable to decide matters for himself or express his own interiority; he is either Gus's tool or the doctors' specimen. And Walt is well aware of his own marginalisation. After becoming wary of Gus's murderous tendencies and fearing for his own life, Walt attempts to resurrect Heisenberg (Thirty-eight snub 2011). He purchases a handgun with the intent of assassinating Gus, only to reveal Heisenberg's impotence when armed with anything but chemical weapons: as Walt approaches Gus's house to kill the drug lord, he receives a call from one of Gus's henchmen, ordering him to simply go home; Gus's panoptic vision, Walt realises, extends beyond the lab. But where guns fail Walt, science finally does not; Gus's climactic and 
explosive demise at the end of season 4 follows images of Walt cooking up a pipe bomb in his own kitchen with empty icepack wrappers strewn around the floor-a return to the messy, disorganised, and intimate scientific space of the show's beginnings (End Times 2011).

It is necessary to rehearse Walt's interplay with these varying depictions of scientific practice and masculinity because Breaking Bad's ethos depends centrally on its viewers acceptance of Walt as both a masculine hero and a man of science. Recalling Chatman's equation of the implied author with the complete ideological nexus of a text, one might identify behind Breaking Bad an implied author who values both scientific knowledge and rugged individualism (as opposed to the pristine corporatism of the traditional science lab), and, through Walt, invents a rhetorical construction of both. The show's implied author is hardly synonymous with Walt-Walt does bad things, hurts people, and alienates his family, and the show seems fully aware of all thisbut the show does present Walt as an interesting, often likeable character, and someone to (usually) root for. The show, it could be said, uses Walt to fit the narrative needs of the crime drama genre (that is, the need for a gritty masculine hero who will resort to violent measures), and uses science to add a unique and "serious" element to the show, one that sets it apart from other dramas. In the following section, we discuss the intertexual and social effects of this scientific ethos.

\section{The Intertexts of Science and Fiction}

Breaking Bad has received heavy praise, both critical and popular, as an innovative drama. Entertainment Weekly critic Ken Tucker (2009) puts it this way:

Ultimately, [Breaking Bad] is a superlatively fresh metaphor for a middle-age crisis: It took cancer and lawbreaking to jolt Walt out of his suburban stupor, to experience life again - to take chances, risk danger, do things he didn't think himself capable of doing. None of this would work, of course, without Emmy winner Cranston's ferocious, funny selflessness as an actor. For all its bleakness and darkness, there's a glowing exhilaration about this series: It's a feel-good show about feeling really bad. 
This short encomium picks up on numerous aspects of the show that audiences have lauded: its top-notch acting, its sense of humour, the gravity of its subject matter. Such qualities, though, characterise most critically acclaimed dramasnor is there anything novel about the trope of the "good" man who finds himself "breaking bad" in the face of hard times. We believe, though, Breaking Bad's use of science to be a key reason why the show stands out as "a superlatively fresh metaphor”. Dramas centring on lawyers, gangsters, and police officers run in the hundreds, but Breaking Bad is the only drama about a chemistry teacher relying on his unique talents to become the masculine protagonist of a crime narrative. Breaking Bad, it could also be said, has a good sense of kairos-the ancient Greek term for rhetorical timeliness. Public intellectuals from Stephen Hawking to Richard Dawkins to Neil deGrasse Tyson have, in recent years, helped revitalise science as a topic of popular discussion, while political issues like global warming, sustainable energy, and (in the United States) the teaching of intelligent design in schools have placed science at the centre of public debate. In what ways Breaking Bad concretely adds to such debate is hard to say, but the show-through its use of Walt and appeals to scientific accuracy-does seem to have capitalised on a certain public interest in science.

But again, the show has done this without inviting the tag "science fiction" or any of the pejorative "genre fiction" baggage that label entails. Here, it is worth comparing Breaking Bad to a show like the Syfy Channel series Eureka (2006-2012; aired as A Town Called Eureka in the UK), in which Colin Ferguson plays a federal marshal in charge of policing a community of scientists who have been sequestered from society at large in order to better pursue their world-changing technological innovations. Many of the "problems" posed in Eureka's narrative, unsurprisingly, involve science experiments that backfire or scientific creations that run amok. In one sense, it could be argued that Eureka is science fiction and Breaking Bad is not because Eureka's science is fictitious and Breaking Bad's is not. The science of Eureka, though, while speculative, is rarely outlandish. We would argue that principle difference between Breaking Bad and a show like Eureka is not in the veracity of the science, but the rhetorical use of the science to meet genre expectations. Eureka uses science largely to pose "what if?" questions about the possibilities and limits of technology, while Breaking Bad uses science as a credibility- 
booster and an alternate access point into the genre of crime drama. One crucial result of these divergent paths is that Breaking Bad is perceived as "serious" television show-the kind that airs on AMC, draws audiences of up to 2.9 million per episode, and attracts high-profile Emmy and Golden Globe nominations-while Eureka remains "mere" science fiction (see O'Connel 2012).7 One is "genre fiction"; the other is not.

Breaking Bad, though, is hardly the sole crime drama to make use of scientific imagery and discourse. Notably, police procedurals like CSI, Bones, and NCIS often couple scenes of crime-scene detective work with the analytic lab work used to track down and convict criminals. ${ }^{8}$ The science depicted in these shows, though, tends to resemble those scenes in Gus's lab-tidy, clinical, and cut together from comfortable, clichéd images of scientific procedure-more than the raw, viscerally "real" (and scientifically veracious) scenes of Walt and Jesse cooking in the RV or disintegrating corpses in acid. These shows also tend to feminise the lab workers-who are represented as chatty and bookish-in contradistinction to the masculine field investigators, who are stoic, dutiful, and bold in the face of danger. Walt, of course, oscillates between these two character types over the course of Breaking Bad's macro narrative. What chiefly sets Breaking Bad apart from police procedurals, though, is its use of Walt's character evolution to enact what Chatman calls a narrative of "revelation". In police procedurals, and in shows like Eureka, the dominant form is the "narrative of resolution", in which, as Chatman puts it, "there is a sense of problem solving, of things being worked out in some way" (1978, pg. 48). Police procedurals tend take an episodic form, pose one major problem at a time-a murder or other crime that needs solving - to which they apply their formula of investigation and lab work (along with formulaic images of lab work) to achieve resolution. In the plot of revelation, though, "[i]t is not that the state of affairs are resolved (happily or tragically), but rather that a state of affairs is revealed" (Chatman 1978, pg. 48). Breaking Bad's plot fits this mould better; it tends to generate more loose ends than it ties up, and the result, as we mention above, is a meandering exploration of numerous economic and social issues. This narrative form is another reason, we believe, why the show has been perceived as "serious" television. And in Breaking Bad, science is a point of access into this serpentine narrative structure, rather than an agent of tidy resolution. 
Breaking Bad's narrative of revelation, finally, has also invited comparisons to The Wire (2002-2008), which enacts a narrative of revelation par excellence in its panoramic exploration of the drug-dealing industry in Baltimore. Breaking Bad, which began right as The Wire was wrapping up, has the tighter scope of the two, but both share a good deal of subject matter about the economics of drug-dealing. One imagines that the creators of Breaking Bad felt obliged to set themselves apart from The Wire as they conceived their own show, and Walt's chemistry, again, provides the means: The Wire probes almost every facet of the social apparatus surrounding Baltimore's drugdealing trade-the dealers, the police, the schools, the local and state politics, the newspapers-but it does not address the science of drug-production. It is likely a testament to the scientific ethos of Breaking Bad that the show has thrived as a "serious" drama about the drug industry without being labelled a knockoff, or The Wire 2.0.

\section{Conclusion: Science / Fiction / Rhetoric}

We want to stress that our discussion of Breaking Bad's rhetorical tactics should not be taken as a denunciation of the show or a reduction of its narrative components to "mere" rhetoric. We wish to invoke the term "rhetoric" without pejorative connotation, and we believe that all effective fiction-television, film, literature, etc.-must make use of rhetoric. As Chatman puts it, "there are two narrative rhetorics, one concerned to suade me to accept the form of the work; another, to suade me of a certain view of how things are in the world" (1990, pg. 203). We maintain that all fictional must succeed on both these rhetorical levels to be taken seriously. In Breaking Bad's case, the use of science as an ethical appeal seems to have worked well to suade audiences to accept the form to the work-to accept the show as a credible representation of reality and accept its implied author as a credible commentator.

The rhetorician Kenneth Burke writes that, in a sense, science is often (or perhaps always) linked to rhetoric: "If you would praise God, and in terms that happen also to sanction one system of material property rather than another, you have forced Rhetorical considerations upon us. If you would praise science, however exaltedly, when that same science is at the service of 
imperialist-military expansion, here again you have brought things within the orbit of Rhetoric" (1952, pg. 26). One rhetorical accomplishment of Breaking Bad is to persuasively demonstrate Burke's thesis of how otherwise "pure" science can be swept into a rhetorical matrix of motives-in his example, the motives of imperialist militarism; in the show's example, the motives of capitalist drug-production. The show, to return to Walt and Jesse's prescient conversation in the pilot, demonstrates business's rhetorical usurpation of chemistry. But this same thesis can be turned back on the show itself as an analytic heuristic: this essay has focused on Breaking Bad's appropriation of "pure" science, or images of "pure" science, for the rhetorical motives of verisimilitude and appeals to credibility.

Our concluding point is this: The science invoked in fictional texts is never pure; it always has a rhetorical purpose. By our estimation, it matters less whether or not a show like Breaking Bad counts as science fiction than it does how the show rhetorically uses science, for what ends, and what this use of science says about audience expectations. We hope to have elucidated Breaking Bad's use of science as an appeal to credibility, but we have hardly tied matters up in our own "narrative of resolution”. Questions linger, for instance, about the implications of the show's transformation of Walt (to the glee of many) into a troubling stereotype of masculinity, and about why, exactly, "science fiction" struggles for respect when other fiction can use science to gain respect. These are questions for further studies. Those studies, we hope, will take up rhetoric as a primary concern.

\section{Notes}

1. At the time of this article's composition, Breaking Bad has recently begun its fifth and reportedly final season. The first four seasons, spanning 2008-12, include 46 episodes.

2. See also Booth 2002. Booth maintains that all effective films evince a coherent "implied author"-a separate entity from the director, stars, and other flesh-and-blood contributorsat the center of their composition. We think a similar argument can be made of television 
texts, one that accounts for the construction of ethos across temporally displaced seasons and episodes.

3. See also Rohn [no date]. The website LabLit.com: The Culture of Science in Fiction and Fact (http://www.lablit.com/) provides a popular counterpart to Kirby's scholarly commentary on cultural representations of science.

4. See also Kirby 2011, pp. 112-117; scientific consultants, Kirby notes, generally acknowledge the value of suspending scientific accuracy for dramatic proposes, though they often object to texts that warp public perception of fundamental scientific knowledge or advance "pseudoscience" as truth.

5. There is, it seems to us, much more to be written about the thematic tension between science and masculinity in texts ranging from Frankenstein to Dr. Jekyll and Mr. Hyde to The Six Million Dollar Man to MacGyver to The Big Bang Theory. We discuss several avenues of this tension here as they relate to Breaking Bad's ethos, but Walt's place in the history of manly and not-so-manly fictional scientific protagonists warrants its own paper.

6. Both of Foucault's texts discuss the use of vision and surveillance to reduce individuals in need of "correction" to discursive constructions of observable data, effectively erasing human interiority.

7. Note also that one of the few American television shows to receive both the label "science fiction" and recognition as a "serious" drama was The X-Files, for which Breaking Bad's Vince Gilligan was a writer, producer, and occasional director.

8. See Kruse 2010. After a careful reading of the show's insistence that science leads to truth and justice, Corinna Kruse argues that "CSI creates a cultural repertoire with which to imagine perfect justice" (pg. 84). Additionally, she examines the so-called "CSI effect", in which lay-people who participate in the justice system come to expect forensic evidence to work as it does on CSI, providing absolute certainty of guilt instead of often ambiguous probabilities. Similarly, it is worth exploring the ethical questions of how Breaking Bad might influence viewers to perceive chemistry, meth production, and the DEA unrealistically, but these are topics for another essay. 


\section{Bibliography}

Aristotle, 1954. Rhetoric. In: Aristotle's Rhetoric and Poetics. Translated by Roberts and Bywater. New York: Modern Library, pp. 1-218

Booth, W., 1983. The rhetoric of fiction. $2^{\text {nd }}$ edition. Chicago: $\mathrm{U}$ of Chicago $\mathrm{P}$ 2002. Is there an "implied" author in every film? College Literature 29(2), pp. 124-131

Burke, K., 1952. A rhetoric of motives. New York: Prentice Hall

Cat's in the bag... [episode], 2008. Breaking bad [on DVD]. Television programme. New York: American Movie Classics, 27 January

Chatman, S., 1978. Story and discourse: narrative structure in fiction and film. Ithaca: Cornell UP 1990. Coming to terms: the rhetoric of narrative in fiction and film. Ithaca: Cornell UP

Crazy handful of nothin' [episode], 2008. Breaking bad [on DVD]. Television programme. New York: American Movie Classics, 2 March

End times [episode], 2011. Breaking bad [on DVD]. Television programme. New York: American Movie Classics, 2 October

Eureka [on DVD], 2006-2012. New York: Syfy

Flatow, I. and Nelson, D., 2011. The science behind Breaking Bad [Online]. Available at: http://www.npr.org/2011/12/23/144190095/the-sciencebehind-breaking-bad [Accessed: 26 July 2012]

Fly [episode], 2010. Breaking bad [on DVD]. Television programme. New York: American Movie Classics, 23 May

Foucault, M., 1975. The birth of the clinic: an archeology of medical perception. Trans. Smith. New York: Vintage 1995. Discipline and punish: the birth of the prison. Trans. Sheridan. New York: Vintage 
Gray matter [episode], 2008. Breaking bad [on DVD]. Television programme. New York: American Movie Classics, 24 February

Kirby, D., 2011. Lab coats in Hollywood: science, scientists, and cinema. Cambridge: MIT UP

Kruse, C., 2010. Producing absolute truth: CSI science as wishful thinking. American Anthropologist 112(1), pp. 79-91

Peekaboo [episode], 2009. Breaking bad [on DVD]. Television programme. New York: American Movie Classics, 12 April

Pilot [episode], 2008. Breaking bad [on DVD]. Television programme. New York: American Movie Classics, 20 January

O’Connel, M., 2012. Breaking Bad mid-season finale ratings fall just shy of recent record [Online]. Available at: http://www.hollywoodreporter.com/livefeed/breaking-bad-mid-season-five-finale-ratings-367826 [Accessed: 7 October 2012]

Over [episode], 2009. Breaking bad [on DVD]. Television programme. New York: American Movie Classics, 10 May

Rohn, J., ed. [No date]. LabLit.com: the culture of science in fiction and fact [Online]. Available at: http://www.lablit.com/ [Accessed: 7 October 2012]

Thirty-eight snub [episode], 2011. Breaking bad [on DVD]. Television programme. New York: American Movie Classics, 24 July

Tucker, K., 2009. Breaking bad [Online]. Available at: http://www.ew.com/ew/ article/o,,20261336,00.html [Accessed: 26 July 2012]

TV Tropes Foundation, [No date]. And some other stuff [Online]. Available at: http://tvtropes.org/pmwiki/pmwiki.php/Main/AndSomeOtherStuff [Accessed: 26 July 2012]

The wire [on DVD], 2002-2008. New York: HBO 